\title{
Obesity, pregnancy, inflammation, and vascular function
}

\author{
F C Denison, K A Roberts, S M Barr and J E Norman \\ Queen's Medical Research Institute, Centre for Reproductive Biology, 47 Little France Crescent, \\ Edinburgh, EH16 4TJ, UK \\ Correspondence should be addressed to FC Denison; Email: fiona.denison@ed.ac.uk
}

\begin{abstract}
Maternal obesity is associated with increased morbidity and mortality for both mother and offspring. The mechanisms underlying the increased risk associated with maternal obesity are not well understood. In non-pregnant populations, many of the complications of obesity are thought to be mediated in part by inflammation and its sequelae. Recent studies suggest that a heightened inflammatory response may also be involved in mediating adverse clinical outcomes during pregnancy. This review summarizes our current knowledge about adipose tissue biology, and its role as an endocrine and inflammatory organ. The evidence for inflammation as a key mediator of adverse pregnancy outcome is also presented, focusing on the role of inflammation in adipose tissue, systemic inflammation, the placenta, and vascular endothelium.

Reproduction (2010) 140 373-385
\end{abstract}

\section{Clinical impact of maternal obesity on pregnancy}

Human obesity is an increasingly common condition among both sexes, with an estimated prevalence of $4-28 \%$ among European men and $6-37 \%$ among European women (Berghofer et al. 2008). The prevalence of obesity is also increasing in women of reproductive age, and currently it is estimated that more than one in five pregnant women are obese (Heslehurst et al. 2007, 2009). Maternal obesity is associated with increased morbidity and mortality for both mother and offspring. Antenatal risks include gestational diabetes and hypertensive disorders including pre-eclampsia and thromboembolic complications (Sebire et al. 2001, Bhattacharya et al. 2007, Denison et al. 2008). Peripartum, women are more likely to face induction of labor, operative delivery, and postpartum hemorrhage (Sebire et al. 2001, Denison et al. 2008). High pregravid body mass index (BMI) and excessive gestational weight gain are also important predictors of short-term postpartum morbidity and higher postpartum weight retention (Gunderson et al. 2001), with the latter being associated with increased risks during future pregnancies and of lifelong obesity for women (Oken et al. 2008). Offspring of obese mothers tend to be large for gestational age at birth and are at a higher risk of late

\footnotetext{
This paper is one of five papers that form part of a special Focus Issue section on Obesity. The Guest Editor for this section was J E Norman, Edinburgh, UK; she was not involved in the handling of this paper, on which she is listed as an author.
}

fetal death, congenital anomaly, and admission to the neonatal unit. Maternal obesity also increases the lifetime risk of obesity in offspring and a tendency to develop metabolic syndrome in childhood and adolescence (Boney et al. 2005), thus perpetuating the cycle of obesity and its adverse consequences into the next generation. The mechanisms underlying the increased risk associated with maternal obesity are not well understood. However, many of the complications of obesity in non-pregnant populations are thought to be mediated in part by inflammation and its sequelae. Recent studies suggest that a heightened inflammatory response, both locally (adipose tissue, placenta, and vascular endothelium) and systemically (circulating plasma concentrations), may also be involved in mediating adverse clinical outcomes during pregnancy. This article reviews the evidence which links maternal obesity, local and systemic inflammation, and adverse pregnancy outcomes.

\section{Adipose tissue biology}

Obesity involves a massive expansion of adipose tissue, with a disproportionately smaller expansion of other tissue types within the body. Over the last decade, there has been a paradigm shift in the understanding of the nature of adipose tissue. It is now known that fat is not just a storage organ, but it is a highly active tissue metabolically, comprising one of the largest endocrine organs in the body. In obesity, expansion of adipose tissue mass is associated with increasing inflammation of 
adipose tissue, and there is emerging evidence that this inflammation is causally linked both to insulin resistance and to other obesity-related morbidities such as cardiovascular disease. To date, much of the evidence in this area comes from the studies on nonpregnant individuals, with much less information on adipose tissue biology in pregnant women. In this section, we will attempt to review current understanding of adipose tissue ontogeny and function, how it becomes disordered in obesity, and the possible impact both of pregnancy on adipose tissue biology and of adipose tissue expansion and inflammation on pregnancy disorders.

Mature adipose tissue consists of adipocytes and stromal vascular cells, with the latter including vascular endothelial cells, fibroblasts, and cells of the hematopoietic lineage. Immature adipose tissue first appears in the fetus between 14 and 16 weeks of gestation. The stages in adipose development are as follows: i) emergence of undifferentiated loose connective tissue clusters, ii) mesenchymal condensation associated with angiogenesis, iii) differentiation of mesenchymal cells into preadipocytes within a vascular matrix, iv) emergence of primitive fat lobules characterized by the appearance of fat vacuoles appearing in the cytoplasm of the mesenchymal cells, and v) appearance of definitive fat lobules: fat lobules well separated from each other by dense septae of perilobular mesenchymal tissue (Poissonnet et al. 1983). In terms of location, adipose tissue becomes first noticeable in the fetus at the head and neck, followed by the trunk, and finally in the upper and lower limbs (Poissonnet et al. 1984). By 28 weeks of gestation, fat tissue is present in the fetus in the six principal fat deposit areas: the face (buccal and ocular pads, cheek, and chin), the neck, the thorax (anterior and posterior chest wall, and mammary area), the abdomen (abdominal wall and perirenal), the upper limb (shoulder, forearm, arm, and hand), and the lower limb (gluteus, thigh, leg, and foot), and the number of fat lobules in adipose tissue is likely complete, with further adipose tissue expansion being mostly due to an increase in the size of fat lobules (Poissonnet et al. 1984). However, the development of obesity during childhood can further increase the number of adipocytes, with greater adipocyte number in obese individuals compared with lean individuals being obvious as early as 1 year (Knittle et al. 1979). In contrast, once adulthood is reached, adipose cell number likely remains constant, with obesity due to an expansion of adipose cell size, except possibly in extreme obesity (Spalding et al. 2008). Importantly, different types and sites of adipose tissue have different functions. All mammals contain white adipose tissue (WAT) and brown adipose tissue, with specific functions of lipid storage and thermogenesis respectively, with possible transdifferentiation between the two (Cinti 2009). Additionally, in many animals including humans, visceral adipose tissue, which surrounds internal organs, is more important than subcutaneous adipose tissue in the development of the metabolic syndrome (Despres \& Lemieux 2006).

\section{Adipose tissue as an endocrine organ}

The concept that adipose tissue has actions far beyond the mere storage of triglycerides began in 1993 with the demonstration that the adipocytes in mouse adipose tissue generate tumor necrosis factor $\alpha$ (TNF), and with obese animals having greater adipose-specific TNF expression and greater circulating levels of TNF (Hotamisligil et al. 1993). A strong relationship between adipose tissue TNF production and insulin resistance was also identified, with cause and effect being confirmed by experiments showing that TNF antagonism reduced peripheral insulin resistance in this mouse model (Hotamisligil et al. 1993). The following year, leptin, the product of the $o b$ gene (deletion of which causes profound obesity), was identified as a major secretory product of adipose tissue, and the model of adipose tissue as an endocrine organ became firmly established (Zhang et al. 1994). TNF and leptin are examples of 'adipokines', peptides released by adipose tissue, and which can signal to distant tissues (Hotamisligil et al. 1993). In humans, WAT produces over 50 'adipokines', including TNF which contributes to the low-grade inflammation found in obesity, leptin which has effects on food intake, and a host of other agents with a variety of effects (Lago et al. 2007, Maury \& Brichard 2010). Table 1 lists some of the major adipokines and their functions. In parallel with these proinflammatory events, WAT also produces antiinflammatory cytokines such as adiponectin (which, paradoxically, tends to be lower in obese individuals) and interleukin (IL)10 and IL1R1 (IL-1R $\alpha$; production of which is proportional to body weight). These inflammatory markers, although originating in fat, circulate and are measurable in serum.

In obesity, there is an upregulation of chemokine and receptor synthesis in both visceral and subcutaneous adipose tissues (Huber et al. 2008), albeit with a greater increase in visceral adipose tissue (Fain et al. 2004), and this is likely a mechanism by which visceral adipose tissue is more strongly associated with the metabolic syndrome than the subcutaneous adipose tissue (Demerath et al. 2008). Cytokines secreted by visceral adipose tissue are 'sensed' directly by the liver due to venous drainage from this adipose depot via the portal system. Thus, visceral adipose tissue is plausibly capable of influencing hepatic glucose homeostasis and insulin sensitivity (Tordjman et al. 2009). Figure 1 summarizes the potential interactions between adipose tissue and distant organs.

Inflammatory gene expression in fat is closely positively correlated with both liver fat content and systemic arterial dysfunction (the latter assessed using 
Table 1 Key adipokines expressed and secreted by adipose tissue and their functions.

\begin{tabular}{|c|c|c|}
\hline Adipokine & Changes in obesity & Functional effects \\
\hline \multicolumn{3}{|l|}{ 'Proinflammatory' cytokines } \\
\hline \multirow[t]{5}{*}{ Tumor necrosis factor $\alpha(\mathrm{TNF})$} & $\uparrow$ Circulating (Cartier et al. 2008) & Activity is predominantly paracrine \\
\hline & $\leftrightarrow$ Circulating levels & Stimulates lipolysis \\
\hline & \multirow[t]{3}{*}{$\begin{array}{l}\leftrightarrow \text { mRNA expression, but } \uparrow \text { release } \\
\text { by cultured adipose (Kern et al. 2001) }\end{array}$} & $\begin{array}{l}\text { Increases insulin resistance via interference } \\
\text { with IRS1 downstream signalling }\end{array}$ \\
\hline & & Impairs preadipocyte differentiation \\
\hline & & Downregulates anti-inflammatory pathways \\
\hline $\begin{array}{l}\text { Chemokine (C-C motif) ligand } 2 \\
\text { (CCL2; also known as MCP-1) }\end{array}$ & $\begin{array}{l}\uparrow \text { Expression in WAT (Bruun et al. 2005, } \\
\text { Di Gregorio et al. 2005) }\end{array}$ & Promotes monocyte recruitment into WAT \\
\hline Interleukin (IL)6 & $\begin{array}{l}\uparrow \text { Circulating levels correlate with } \\
\text { visceral adiposity (Sabio et al. 2008, } \\
\text { Maury \& Brichard 2010) }\end{array}$ & $\begin{array}{l}\text { Secretion by adipose tissue leads to } \\
\text { hepatic insulin resistance in } \\
\text { upregulation of SOCS3 }\end{array}$ \\
\hline IL8 & $\uparrow$ Circulating (Straczkowski et al. 2002) & Potent chemoattractant \\
\hline IL1B & $\uparrow$ Expression (Juge-Aubry et al. 2003) & $\begin{array}{l}\text { Impairs insulin signaling by downregulation of IRS1 } \\
\text { Cytotoxic effects on pancreatic islet cells }\end{array}$ \\
\hline \multicolumn{3}{|l|}{ Anti-inflammatory cytokines } \\
\hline \multirow[t]{2}{*}{ IL10 } & $\downarrow$ Circulating (Esposito et al. 2003) & Broad anti-inflammatory activity \\
\hline & $\uparrow$ Circulating (Juge-Aubry et al. 2005) & $\begin{array}{l}\text { Decreases cytokine production by monocytes } \\
\text { Decreases monocyte activation }\end{array}$ \\
\hline IL1R1 (IL-1R $\alpha)$ & $\uparrow$ Circulating (Meier et al. 2002) & Antagonizes IL1 \\
\hline \multicolumn{3}{|l|}{ Hormones } \\
\hline \multirow[t]{2}{*}{ Leptin } & \multirow[t]{2}{*}{$\uparrow$ Circulating (Heinonen et al. 2005) } & Acts centrally on appetite centers in the brain \\
\hline & & $\begin{array}{l}\text { Stimulates fatty acid oxidation in the liver and } \\
\text { skeletal muscle } \\
\text { Induces secretion of IL1R1 }\end{array}$ \\
\hline \multirow[t]{5}{*}{ Adiponectin } & \multirow{5}{*}{$\begin{array}{l}\downarrow \text { Circulating (Arita et al. 1999, } \\
\text { Maury \& Brichard 2010) }\end{array}$} & Stimulates fatty acid oxidation via ADIPOR1 \\
\hline & & Activates PPARG via ADIPOR2 \\
\hline & & Reduces hepatic gluconeogenesis \\
\hline & & Antagonizes some actions of TNF \\
\hline & & Induces secretion of IL10 \\
\hline \multirow[t]{2}{*}{ Visfatin } & $\uparrow$ Expression in visceral adipose & Regulates $\beta$-cell function in pancreas \\
\hline & $\begin{array}{l}\downarrow \text { In subcutaneous adipose } \\
\quad \text { (Rasouli \& Kern 2008) }\end{array}$ & Role unclear in humans \\
\hline \multirow[t]{2}{*}{ Resistin } & $\uparrow$ Expression in mice & Increases secretion in murine model \\
\hline & $\leftrightarrow$ In humans (Janke et al. 2002) & Role unclear in humans \\
\hline \multirow[t]{3}{*}{ Apelin } & $\uparrow$ Circulating (Heinonen et al. 2005) & Central action on feeding behavior \\
\hline & & Infusion restores glucose tolerance in mice \\
\hline & & Role unclear in humans \\
\hline \multicolumn{3}{|c|}{ Adipokines involved in vitamin A metabolism } \\
\hline \multirow[t]{2}{*}{$\begin{array}{l}\text { Retinol-binding } \\
\text { protein }(\mathrm{RBP}) 4\end{array}$} & $\begin{array}{l}\uparrow \text { Expression/circulating (Rasouli \& } \\
\text { Kern 2008, Maury \& Brichard 2010) }\end{array}$ & $\begin{array}{l}\text { Increases insulin resistance in animal } \\
\text { studies (Yang et al. 2005) }\end{array}$ \\
\hline & & Role unclear in humans \\
\hline \multicolumn{3}{|l|}{ Other factors } \\
\hline $\begin{array}{l}\text { Plasminogen activator } \\
\text { inhibitor (PAI) } 1\end{array}$ & $\uparrow$ Secretion (Maury \& Brichard 2010) & $\begin{array}{l}\text { Oversecretion leads to decreased } \\
\text { fibrinolysis and excessive thrombosis }\end{array}$ \\
\hline Angiotensinogen & $\uparrow$ Circulating (Maury \& Brichard 2010) & $\begin{array}{l}\text { Increases fat mass and hypertension } \\
\text { in transgenic mice }\end{array}$ \\
\hline Prostaglandins & $\begin{array}{l}\downarrow \text { Release of } \mathrm{PGE}_{2} \text { by cultured adipose } \\
\text { tissue (Fain et al. 2004, } \\
\text { Hétu \& Riendeau 2007) }\end{array}$ & Inhibits adipocyte lipolysis \\
\hline
\end{tabular}

ultrasound), and inversely correlated with whole body insulin sensitivity and omental lipogenic factors (Makkonen et al. 2007, Apovian et al. 2008, PoulainGodefroy et al. 2008). A recent study in a rodent model has demonstrated that i.v. infusion of each of TNF and CCL2 (also known as monocyte chemoattractant protein-1, MCP-1; Tateya et al. 2010) induced features of the metabolic syndrome, and blockade of TNF with drugs such as infliximab has been reported to improve insulin sensitivity in a murine model (Araujo et al. 2007). Together, these studies suggest that adipokines may have a more causal relationship with the metabolic syndrome that has been recognized previously. In addition to cytokines, the enzyme $11 \beta$-hydroxysteroid dehyrodgenase type 1 , which is involved in intra-adipose regulation of local bioavailability of active corticosteroid, is also significantly increased in adipose tissue in obese/overweight individuals compared with nonobese individuals (Paulsen et al. 2007, Wake et al. 2007, Morton \& Seckl 2008). This key enzyme is likely to modulate local inflammatory responses within adipose tissue. 


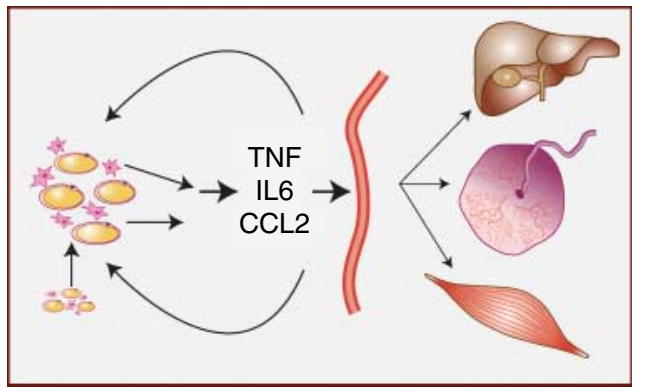

Figure 1 Adipose tissue is a source of inflammatory mediators with local and systemic effects. Adipocytes and cells of the stromal vascular fraction can secrete inflammatory cytokines such as TNF, IL6, and CCL2 (MCP-1). These have local autocrine and paracrine effects, but may also contribute to elevated circulating levels in obesity, with systemic effects including modulation of hepatic and skeletal muscle insulin signaling, and potential effects on placenta.

\section{Inflammation in adipose tissue}

Although the association between obesity, low-grade inflammation, and insulin resistance is propagated in part by adipokines generated by adipocytes and cells of the stromal vascular fraction as described above, an influx of inflammatory cells into adipose tissue is also implicated (Xu et al. 2003, Hotamisligil 2006). Originally, it was thought that cells of the innate immune system were the major players in this event, but increasing evidence implicates $\mathrm{T}$ cells and possibly other leukocytes (Lumeng et al. 2009). However, the predominant leukocytes in adipose tissue are macrophages, which are present in the stromal vascular fraction and their density is in direct proportion to the levels of obesity (Weisberg et al. 2003). Indeed, there is a significant functional overlap between adipose tissue and macrophage biology, with both (under the correct conditions) being phagocytic; producing transcription factors, cytokines, inflammatory molecules, fatty acid transporters, and scavenger receptors; and with some evidence that preadipocytes can be 'converted' to macrophages (Charriere et al. 2003, Wellen \& Hotamisligil 2003).

Adipose tissue macrophages (ATMs) are found in both lean and obese individuals, and have been identified in 'crown-like structures' (SM Barr, JE Norman, BR Walker \& NM Morton, 2009, unpublished observations; Fig. 2) surrounding the necrotic adipocytes. However, their functional activity is proportional to the degree of obesity (Lumeng et al. 2007), and may reflect the need for additional scavenger activity due to additional adipocyte death as a result of disordered hypertrophy (Zeyda \& Stulnig 2007). ATMs have a distinct phenotype, being typical of neither M1 nor M2. In lean individuals, ATMs more closely resemble the M2 'alternatively activated' phenotype, secreting anti-inflammatory cytokines such as IL10 and IL1 decoy receptor, and also secreting arginase which blocks inducible nitric oxide synthase (NOS2, also known as iNOS) activity; however they are capable of significant proinflammatory cytokine production (Zeyda et al. 2007) on stimulation with interferon- $\gamma$. In contrast, in obese individuals, there is a shift toward the M1 'classically activated' phenotype, secreting proinflammatory cytokines TNF, IL6, and IL12, and generating reactive oxygen species such as nitric oxide via activation of NOS2 (Lumeng et al. 2007).

$\mathrm{T}_{\mathrm{H}} 2$ cytokines are the likely drivers toward the M2 phenotype of ATMs in lean individuals (Lumeng et al. 2007). With the development of obesity, there is both a change in macrophage phenotype toward M1 and an increase in macrophage density (probably as a result of invasion of new macrophages from the bloodstream rather than local proliferation of macrophages (Weisberg et al. 2003)). These invading and activated macrophages then interact with adipocytes to initiate vicious cycle of macrophage recruitment, production of inflammatory cytokines, and impairment of adipocyte function (Wellen \& Hotamisligil 2003). As with adipokine production, the increase in macrophage density in adipose tissue is greater in visceral deposits than in subcutaneous deposits (Harman-Boehm et al. 2007). Additionally, increased macrophage invasion into the adipose tissue is associated with insulin resistance, an important component of the metabolic syndrome (Xu et al. 2003). A feedback loop likely exists, since treatment with an insulin-sensitizing agent (rosiglitazone) in a mouse model of obesity reduces markers of macrophage density (Xu et al. 2003). The adverse metabolic effects of ATM invasion are not limited to insulin resistance: endothelial dysfunction in obesity is also related to ATM number and activity (Apovian et al. 2008).

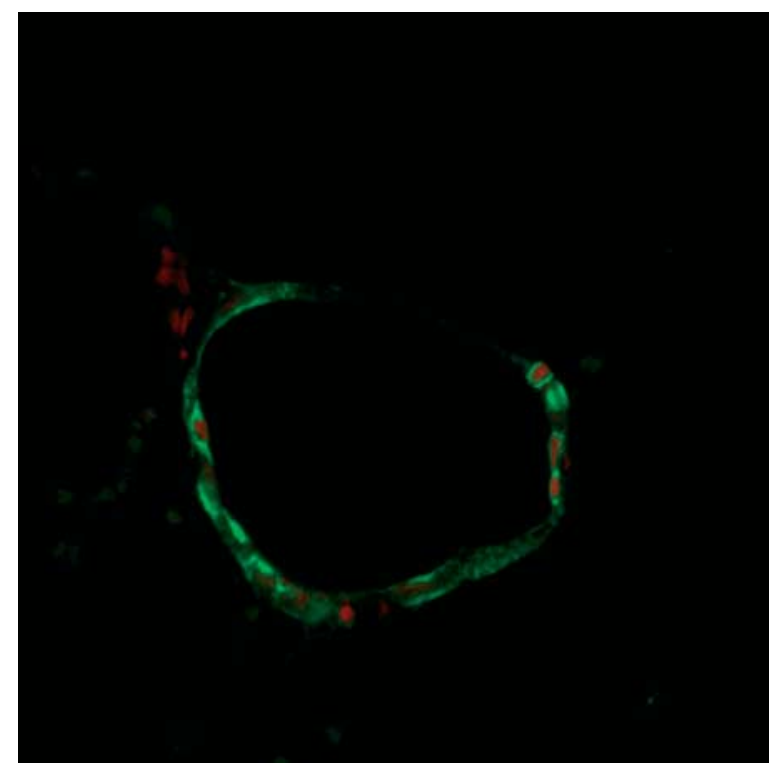

Figure 2 Macrophages can be identified in adipose tissue surrounding dead adipocytes in 'crown-like' structures. Obesity is associated with macrophage infiltration into adipose tissue, plausibly in response to disordered adipocyte hypertrophy and necrosis. 
The change in ATM phenotype in obesity is likely to be driven by the action of $T_{H} 1$ cytokines, with emerging data suggesting that T cells in adipose tissue play a major role in regulating ATM phenotype and function (Lumeng et al. 2009). As with ATM biology, much of the information on $\mathrm{T}$ cell function in adipose tissue comes from mouse studies. In lean mice, CD3 + T cells account for just under $15 \%$ of the stromal vascular cell fraction in adipose tissue (Nishimura et al. 2009). Obesity in mice is associated with a greater adipose tissue density of CD8 $+\mathrm{T}$ cells (largely effector $\mathrm{T}$ cells) and a lower density of CD4 $+\mathrm{T}$ cells and Treg cells (Feuerer et al. 2009, Nishimura et al. 2009, Winer et al. 2009). Temporally, CD8 + cell invasion precedes that of reduced $\mathrm{CD} 4+$ and reduced Treg cell density in adipose tissue following diet-induced obesity, and both changes are followed by an increase in macrophage density (Nishimura et al. 2009). These data, together with data from CD8+-depleted mice and/or mice in which CD8 + cell activity was blocked, show that CD8 + cells are necessary for both initiation and maintenance of ATM invasion, particularly M1 macrophages. Importantly, CD8 + activity and decreased Treg cell density also appear to be crucial in the pathogenesis of the insulin resistance that accompanies obesity (Feuerer et al. 2009, Nishimura et al. 2009, Winer et al. 2009).

Thus, $\mathrm{T}$ cells appear to be major regulators in controlling ATM number and function in mouse and in human obesity (Kintscher et al. 2008). However, the question of what initiates adipose tissue inflammation remains incompletely answered. Although necessary, CD8 + cells alone are not sufficient to initiate macrophage invasion, differentiation, and activation in adipose tissue: interactions between CD8 + T cells and adipose tissue are required (Nishimura et al. 2009). The factor(s) triggering the type of interaction between $\mathrm{T}$ cells and adipose tissue that will initiate macrophage recruitment and phenotypic change are unknown, but free fatty acid-induced physical stress or oxidative damage to the endothelium (Wellen \& Hotamisligil 2003) (possibly mediated via Toll-like receptors) (Schaeffler et al. 2009), hypoxia, and adipocyte death have all been proposed (Lumeng et al. 2009) as the initiating factors.

Whether macrophages and $\mathrm{T}$ cells are the only important leukocytes in adipose tissue inflammation is unclear. For example, the activity of mast cells in adipose tissue may also be relevant - obesity is associated with increasing mast cell density in WAT in both humans and rodents (Liu et al. 2009), and reducing mast cell numbers in a mouse model of diet-induced obesity reduces body weight and insulin resistance, probably via decreased adipocyte apoptosis and angiogenesis (Liu et al. 2009). The possible efficacy of mast cell-stabilizing agents as therapies to prevent/treat obesity is demonstrated by the association between $\mathrm{BMI}$ and serum tryptase (a mast cell product) levels after adjustment for gender (Liu et al. 2009).

\section{Maternal studies}

Fewer studies have looked at the link between obesity and inflammation during pregnancy. In a study of 47 women, serum levels of leptin, CRP, and IL6 were higher in obese women compared with gestation-, smoking-, and parity-matched lean women (Ramsay et al. 2002). These findings were confirmed in a subsequent study by the same group, which also showed higher serum ICAM-1 levels and lower plasminogen activator inhibitor (PAI)1:PAl2 ratios in obese women compared with non-obese pregnant women (Stewart et al. 2007). This increase in circulating proinflammatory cytokines relates in part to production by maternal peripheral blood mononuclear cells, which show greater TNF and IL6 mRNA production and expression of differentiation and activation markers (CD14 and CD68; Challier et al. 2008).

In contrast to the evidence on macrophage invasion and other inflammatory events in adipose tissue in non-pregnant obese individuals, there have (to our knowledge) been no quantitative studies on these events in pregnant women, although we have identified macrophages and crown-like structures in visceral and subcutaneous adipose tissues from obese pregnant women (SM Barr, JE Norman, BR Walker \& NM Morton, 2009, unpublished observations; Fig. 2). This finding is supported by a recent study in baboons in which maternal obesity was accompanied by macrophage infiltration into adipose tissue (Farley et al. 2009).

In pregnancy, as in the non-pregnant state, obesity and particularly abdominal obesity are associated with glucose intolerance and insulin resistance (Ramsay et al. 2002, Martin et al. 2009), with the result that gestational diabetes is commoner in obese pregnant women. The biochemistry of these events is less well studied in pregnancy. TNF has been shown to be a predictor of insulin resistance in non-obese pregnant women in late gestation (Kirwan et al. 2002), although secretion of TNF from adipose tissue was not different when pregnant women with normal glucose tolerance were compared to lean women with gestational diabetes (Kirwan et al. 2002). However, defects in the insulin signaling cascade have been described in pregnant obese women of normal glucose tolerance in both adipose tissue and skeletal muscle (Colomiere et al. 2009). Given that both glucose intolerance (Metzger et al. 2008) and insulin resistance (seen in women with polycystic ovarian syndrome; Boomsma et al. 2006) are associated with adverse pregnancy outcome, and given their link with obesity in pregnancy, it seems likely that both glucose intolerance (Metzger et al. 2008) and insulin resistance partially mediate the effects of obesity on adverse pregnancy outcome (described above). The increased inflammation found in pregnant and non-pregnant individuals is also plausibly linked to the increased rates of 
pre-eclampsia in obese individuals, given that around $30 \%$ of the effect of increased BMI risk on preeclampsia is related to inflammation and triglyceride levels (Bodnar et al. 2005).

\section{Placental biology}

Inflammation and inflammatory cytokines have a pivotal role in placental function throughout pregnancy. Virtually, all known cytokines are capable of being synthesized and released by cytotrophoblast, syncytiotrophoblast, and resident placental macrophages or Hofbauer cells (Bowen et al. 2002) with their release being developmentally regulated (Hauguel-de Mouzon \& Guerre-Millo 2006). For example, in early pregnancy, coordinated release of IL10 (Pang et al. 2008) and IL11 (Paiva et al. 2007) regulates trophoblast differentiation and invasion (for review see Guzeloglu-Kayisli et al. (2009)), and is therefore involved in the establishment of pregnancy. The physiological role of cytokines in later pregnancy is less well established; however, IL6 and TNF are thought to be involved in the regulation of fetal growth via modulation of expression and activity of the system A, but not L-amino acid transporter (Jones et al. 2009).

Over the last decade, significant advances in our understanding of placental biology have established that placental function is dynamic and influenced by maternal health, and has an important regulatory role in maternal well-being during pregnancy. For example, in women with type 1 diabetes, there is upregulation of placental glycosylation and acylation pathways and a trend toward increased placental weight (Nelson et al. 2009, Radaelli et al. 2009). Moreover, the progressive development of insulin resistance during pregnancy is due in part to placentally derived cytokines (Rusterholz et al. 2007) such as TNF (Kirwan et al. 2002) and leptin (Hauguel-de Mouzon \& Guerre-Millo 2006). Studies have also demonstrated major changes in the placental gene expression profile of inflammatory genes in women who have developed gestational diabetes mellitus (GDM; Radaelli et al. 2009). Given that maternal obesity is accompanied by significant dysregulation of normal physiology, it is therefore plausible that placental structure and function may be altered as a consequence of maternal obesity, and equally, that the placenta may modulate maternal physiology by release of inflammatory cytokines. Table 2 compares the gene expression changes found in placenta from women with GDM with gene expression changes which have been described in placenta from obese women.

\section{The placenta as an inflammatory organ}

There has been a recent trend toward increasing placental weight (Swanson \& Bewtra 2008), paralleling the significant rise in maternal BMl; however, further studies are needed to confirm whether the rise in maternal obesity is responsible for the increase in placental weight. Hypo- or hypercoiling of the umbilical cord, associated with fetal demise and vascular thrombosis (Sebire 2007), is also more common in pregnancies complicated by obesity, gestational

Table 2 Changes in gene expression levels in placenta from women with gestational diabetes mellitus (GDM) and obese women compared to non-obese healthy pregnant women.

\begin{tabular}{|c|c|c|}
\hline Gene & Changes in GDM placenta & Changes in obesity placenta \\
\hline \multicolumn{3}{|l|}{ Proinflammatory cytokines } \\
\hline$T N F$ & $\uparrow$ (Radaelli et al. 2003) & $\uparrow$ (Varastehpour et al. 2006) \\
\hline IL6 & $\leftrightarrow$ (Kleiblova et al. 2010) & $\uparrow$ (Challier et al. 2008) $^{\mathrm{a}}$ \\
\hline IL1 & - & $\uparrow(\text { Challier et al. 2008) })^{\mathrm{a}}$ \\
\hline IL8 & $\leftrightarrow$ (Kleiblova et al. 2010) & - \\
\hline CCL2 & - & - \\
\hline IFNG & $\downarrow$ (Radaelli et al. 2003) & - \\
\hline \multicolumn{3}{|l|}{ Hormones } \\
\hline Leptin & $\uparrow$ (Lepercq et al. 1998) & $\uparrow($ Varastehpour et al. 2006) \\
\hline Leptin receptor & $\uparrow$ (Radaelli et al. 2003) & - \\
\hline Adiponectin & - & _- \\
\hline Adiponectin receptor 1 & $\leftrightarrow$ (Kleiblova et al. 2010) & _- \\
\hline Adiponectin receptor 2 & $\leftrightarrow$ (Kleiblova et al. 2010) & - \\
\hline Resistin & $\leftrightarrow$ (Kleiblova et al. 2010) & - \\
\hline Visfatin & $\leftrightarrow$ (Telejko et al. 2009) & - \\
\hline \multicolumn{3}{|l|}{ Other factors } \\
\hline MIF & $\downarrow$ (Radaelli et al. 2003) & - \\
\hline ESR1 & $\leftrightarrow$ (Kleiblova et al. 2010) & - \\
\hline ESR2 & $\leftrightarrow$ (Kleiblova et al. 2010) & _- \\
\hline PLA2G2A & $\uparrow($ Varastehpour et al. 2006) & - \\
\hline PLA2G5 & $\uparrow($ Varastehpour et al. 2006) & - \\
\hline
\end{tabular}

$\leftrightarrow$, no relative change in gene expression levels; -, change not determined.

${ }^{a}$ Changes in gene expression levels in macrophage population isolated from placenta. 
diabetes, and pre-eclampsia (de Laat et al. 2005). Although these pregnancy complications are all associated with increased inflammation, a causal link between inflammation and cord coiling abnormalities is yet to be established.

At the microscopic level, there are (to our knowledge) no detailed studies examining the effect of maternal obesity on placental structure. However, given that placentae from gestational diabetics have a characteristic morphology (placental immaturity and edema, chorangiosis, and vascular anomalies; Madazli et al. 2008), it is plausible that obesity may also affect placental structure. Supportive of this is a study by Challier et al. (2008) which demonstrates a two- to threefold increase in placental macrophages in obese women compared with non-obese women. The macrophage population was characterized by increased expression of the proinflammatory cytokines IL1, TNF, and IL6, and marked phenotypic heterogeneity with complex subsets of CD14+, CD68+, and CD11b+ (mac-1) cells. A similar placental phenotype has recently been reported in a baboon model of obesity (Farley et al. 2009). It is also possible that maternal obesity may affect the number and function of other immune cell populations (Weisberg et al. 2003, Maroof et al. 2005, Macia et al. 2006) at the maternal-fetal interface including natural killer cells and dendritic cells. Alterations in these cell populations could have lifelong implications for the fetal acquired immune system and disease susceptibility in later life (Challier et al. 2008). Figure 3 summarizes the potential role of inflammation in the placenta and the interactions between maternal and fetal tissues.

Maternal obesity may also affect placental transport and substrate availability. Varastehpour et al. (2006) demonstrated a significant increase in the expression of the phospholipase A2 (PLA2) genes PLA2G2A and PLA2G5 (the main placenta phospholipases), leptin, and TNF in placentae from obese neonates (body fat $>16 \%$ ) compared with lean neonates (body fat $<8 \%$; Varastehpour et al. 2006). By demonstrating that leptin and TNF induced a time-dependent activation of PLA2G2A and PLA2G5, they suggested that this inflammatory loop may be one mechanism by which excess fat accumulates in obese neonates. Alternatively, Elchalal et al. (2005) demonstrated that insulin and fatty acids enhance the expression of adipophilin, which is associated with cellular lipid droplets and implicated in cellular fatty acid uptake and storage of neutral lipids, in term human trophoblasts (Elchalal et al. 2005). In maternal obesity, higher circulating levels of insulin (Challier et al. 2008, Catalano et al. 2009) might therefore upregulate the expression of fatty acid transporters, thereby increasing the availability of fatty acids to both the placenta and the fetus.

Amino acid transport may also be affected by maternal obesity. As described previously, physiological

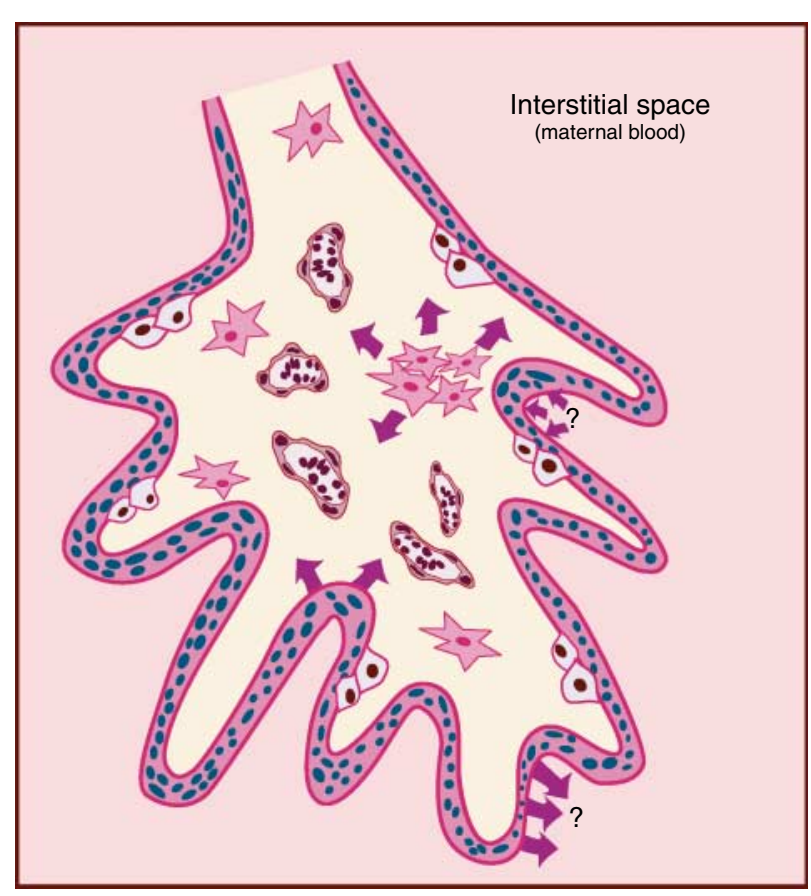

Figure 3 Inflammatory events within the placenta of obese pregnant women. Increased levels of placental macrophages (Hofbauer cells) in conjunction with the cytotrophoblast and syncytiotrophoblast cells are thought to contribute to a heightened inflammatory state within the placenta through the secretion of proinflammatory cytokines such as IL1, TNF, and IL6 (as shown by arrows). An interplay between the trophoblast and immune cells may exist which could further contribute to the heightened inflammatory state of the placenta. It is unclear exactly which proinflammatory cytokines pass through the placenta barrier. However, transfer of proinflammatory cytokines from the maternal circulation across to the placenta could potentially add to the increased local inflammatory state within the placenta. Similarly, proinflammatory cytokines from the placenta may be released into the maternal circulation and contribute to the systemic increase in inflammatory mediators, which is observed in maternal obesity.

concentrations of the proinflammatory cytokines IL6 and TNF stimulate the activity of amino acid transporter system A (Jones et al. 2009). In maternal obesity, increased levels of IL6 and TNF in the placenta could systemically stimulate the system A transporter further, thus increasing amino acid transport to the fetus. Other inflammatory markers that have been demonstrated to differ in placentae from obese animals compared with non-obese animals are carboxypeptidase E (Singh et al. 2006) and resistin (Zhou et al. 2006). Adipokines also modulate placental function. For example, leptin has been shown to regulate placental angiogenesis (Islami et al. 2003), protein synthesis (Perez-Perez et al. 2009), and growth, and cause immunomodulation (Fietta 2005). Thus, it is possible that the increase in local and/or circulating levels of leptin in maternal obesity may modulate placental inflammation and function (Islami et al. 2003, Fietta 2005, Perez-Perez et al. 2009). 
Thus far, the evidence presented suggests that the placenta is a passive bystander in the hostile inflammatory environment of maternal obesity. However, this explanation may be too simplistic. A recent study by Roberts et al. (2009) has demonstrated that although nitrative stress was increased in placentae from obese women compared with non-obese women, this was accompanied by a decrease in oxidative stress. They proposed that the shift in balance between nitrative and oxidative stress may act as a protective mechanism for the placenta with the formation of peroxynitrite consuming reactive oxygen species and reducing oxidative stress. A similar protective mechanism appears to be present in women with gestational diabetes with antioxidant gene expression being increased in placentae from women with gestational diabetes compared with controls (Lappas et al. 2005). Furthermore, when placental explants from women with gestational diabetes were subjected to oxidative stress, expression and release of inflammatory cytokines were reduced compared to explants from normal pregnant women (Lappas et al. 2010). Finally, Colomiere et al. (2009) demonstrated post-receptor defects in the insulin signaling pathway in placentae from obese women compared to non-obese women with significant decreases in expression of mRNA for IR- $\beta$, PI3K p85 $\alpha$, and SLC2A4 (GLUT-4; Colomiere et al. 2009). Together, these studies raise the intriguing possibility that the placenta may be able to 'sense' the maternal environment and adapt to protect not only itself but also potentially the fetus from the hostile inflammatory, oxidative, hyperinsulinemic milieu present in maternal obesity.

\section{Vascular and fibrinolytic function}

In the non-pregnant state, obesity has profound and complex effects on vascular and fibrinolytic function (Stapleton et al. 2008). Clinically, this is reflected by an increased risk of hypertension, atherosclerosis, and ischemic heart disease, and having a myocardial infarction or a cerebrovascular accident. Thus far, most studies investigating the link between obesity and vascular and fibrinolytic function have been undertaken in non-pregnant individuals as opposed to pregnant individuals. In this section, we will review the current evidence linking obesity and inflammation to vascular and fibrinolytic dysfunction in non-pregnant individuals, the effect of pregnancy on vascular and fibrinolytic function, and finally, the combined effect of pregnancy and obesity on these variables.

In obese individuals, local and systemic vascular and endothelial function is significantly impaired. Blood vessel structure is altered in obesity with an increase in vessel diameter, basement membrane thickness, vascular permeability, and vessel stiffness (Zebekakis et al. 2005). With disease progression, microvascular vessel walls start to atrophy, vessel diameter narrows, and progressive microvascular rarefaction develops (Frisbee 2005, Stepp \& Belin De Chantemele 2007), increasing the risk of local tissue ischemia. Adipose tissue, which surrounds blood vessels (perivascular adipose tissue), also indirectly affects vascular structure and tone via release of vasoactive inflammatory mediators including adipokines, angiotensin, and endothelin-1 (Zhang \& Zhang 2009). At a functional level, the vasodilatory response to endothelium-dependent vasodilators such as acetylcholine is attenuated (Steinberg et al. 1996), whereas the response to endothelium-independent vasodilators, such as sodium nitroprusside, remains intact (Van Guilder et al. 2006). Flow-mediated dilation, which induces release of endothelium-dependent relaxing factors increasing blood vessel diameter, is also impaired (Sturm et al. 2009). Vasomotor responses are further blunted by an increase in sensitivity to vasoconstrictive agonists including prostanoids, endothelin-1, and a hyperactivity of the sympathetic nervous system (Esler et al. 2001, Agapitov et al. 2002, Traupe et al. 2002, Frisbee 2006).

Obesity is also associated with a prothrombotic state with plasma concentrations of prothrombotic factors including von Willebrand factor, fibrinogen, and factor VII being higher in obese controls compared with lean controls (Faber et al. 2009). Excess adipose tissue contributes directly to the prothrombotic state by i) impairing platelet function via low-grade inflammation and increase in circulating leptin, ii) impairing fibrinolysis by production of plasminogen activator inhibitor- 1 and possibly thrombin-activatable fibrinolysis inhibitor, iii) impairing coagulation by release of tissue factor, and iv) affecting hepatic synthesis of the coagulation factors fibrinogen, factor VII, factor VIII, and tissue factor, by releasing free fatty acids and proinflammatory cytokines (IL1B, TNF, and IL6) into the portal circulation and by inducing hepatic insulin resistance (Faber et al. 2009).

In order to sustain the developing fetus, extensive cardiovascular adaptation occurs during pregnancy (Robb et al. 2009a, 2009b). Increased production of endothelium-derived vasodilators is accompanied by enhancement of endothelial function and reactivity (Anumba et al. 1999) and an increase in flow-mediated dilation of the brachial artery (Dorup et al. 1999). This is accompanied by a progressive increase in pulse wave velocity and augmentation index over the third trimester (Robb et al. 2009b). These changes occur despite the increase in systemic inflammation (Sacks et al. 1998, 2004), insulin resistance, and hyperlipidemia that occur during normal pregnancy (Sattar \& Greer 2002). Pregnancy is also accompanied by significant alterations in the fibrinolytic and coagulation system with increased plasma concentrations of t-PA, coagulation factors, and inhibitors of fibrinolysis (Hellgren 2003, Robb et al. 2009a) and impaired endogenous fibrinolysis (Robb et al. 2009a). 


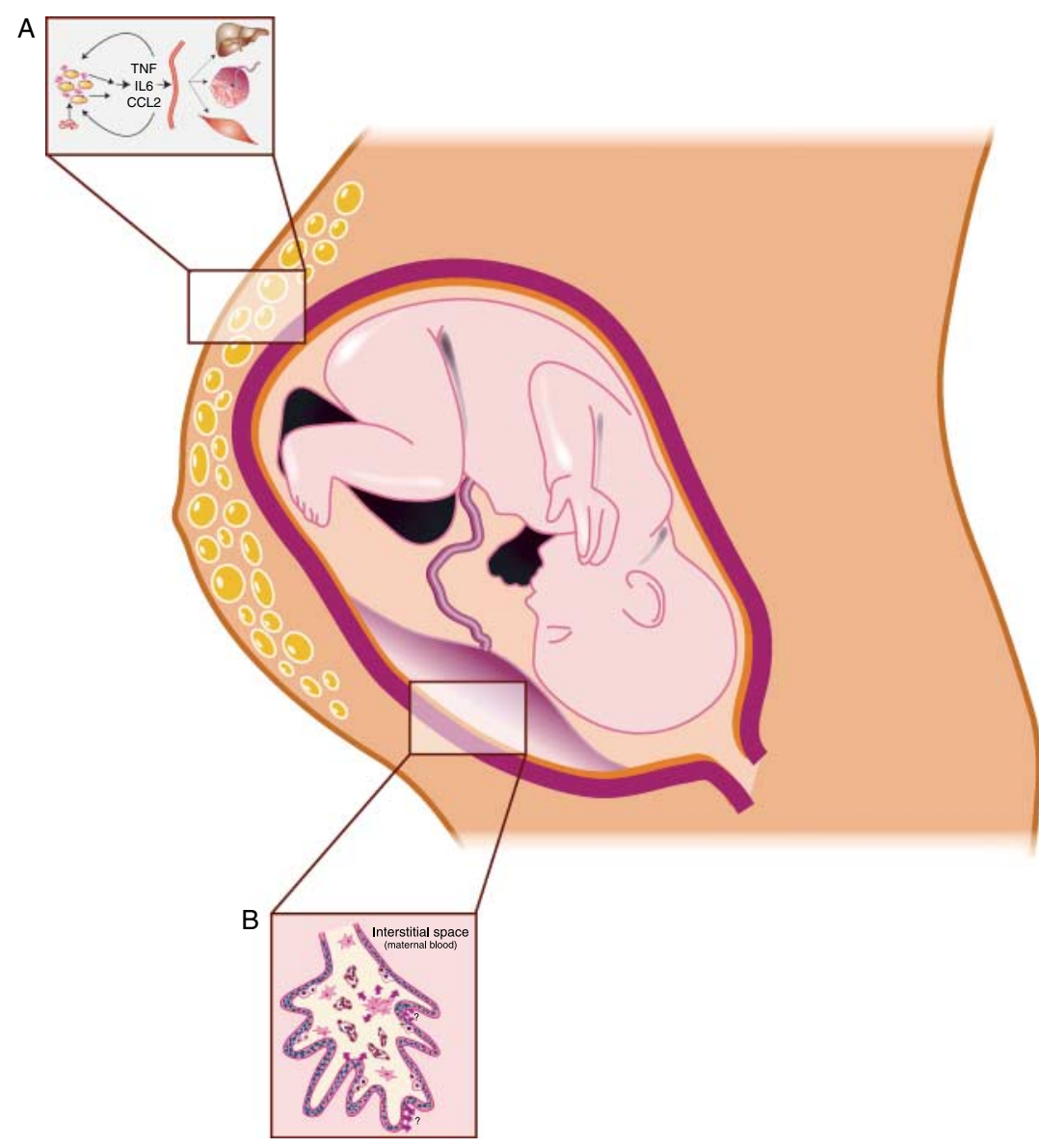

\section{Vascular and fibrinolytic function and inflammation}

Obese women enter pregnancy with chronic preexisting endothelial activation. Although endothelium-dependent function increases during pregnancy in obese and lean women, it remains lower in obese women compared with lean women at all stages of pregnancy (Ramsay et al. 2002, Stewart et al. 2007). Moreover, by 4 months post partum, endothelial function declines to first trimester levels in obese women, whereas improved endothelium-dependent function persists in lean women (Stewart et al. 2007). Endothelium-dependent vasodilation is also impaired in myometrial arteries from women with an elevated BMI at booking compared with those with a BMI within the normal range (Myers et al. 2006). The mechanisms underlying impaired endothelial function in obese women are not well understood. However, it is likely that both systemic (Ramsay et al. 2002, Stewart et al. 2007) and local inflammation within the vasculature are likely to be involved in mediating impaired endothelial function (Walsh 2007). Maternal obesity is also associated with an increased risk of thromboembolism. However (to our knowledge), there are no studies that have compared endogenous fibrinolysis in obese women compared to lean women during pregnancy, nor established whether there are any differences in clotting factors between these groups.

\section{Summary}

Maternal obesity is associated with an increase in maternal and neonatal morbidity and mortality. However, the mechanisms underlying this association remain poorly understood. It is likely that excessive local and systemic inflammation play a key role in the pathophysiology of the adverse outcomes (Fig. 4). Further studies are urgently required to investigate the biology of adipose tissue in obese pregnant women, its links to insulin resistance, circulating inflammatory cytokines, placental, endothelial and fibrinolytic function, and adverse pregnancy outcome. Such studies will inform rational therapies for testing to reduce pregnancyrelated mortality and morbidity among both the mother and the neonate.

\section{Declaration of interest}

The authors confirm that there is no conflict of interest that could be perceived as prejudicing the impartiality of the research reported.

\section{Funding}

Our work on obesity, inflammation, and vascular function in pregnancy was funded by Tommy's, the baby charity, to whom we are very grateful. 


\section{Acknowledgements}

We would like to thank Ronnie Grant for graphical design.

\section{References}

Agapitov AV, Correia ML, Sinkey CA, Dopp JM \& Haynes WG 2002 Impaired skeletal muscle and skin microcirculatory function in human obesity. Journal of Hypertension 20 1401-1405.

Anumba DO, Ford GA, Boys RJ \& Robson SC 1999 Stimulated nitric oxide release and nitric oxide sensitivity in forearm arterial vasculature during normotensive and preeclamptic pregnancy. American Journal of Obstetrics and Gynecology 181 1479-1484.

Apovian CM, Bigornia S, Mott M, Meyers MR, Ulloor J, Gagua M, McDonnell M, Hess D, Joseph L \& Gokce N 2008 Adipose macrophage infiltration is associated with insulin resistance and vascular endothelial dysfunction in obese subjects. Arteriosclerosis, Thrombosis, and Vascular Biology 28 1654-1659.

Araujo EP, De Souza CT, Ueno M, Cintra DE, Bertolo MB, Carvalheira JB, Saad MJ \& Velloso LA 2007 Infliximab restores glucose homeostasis in an animal model of diet-induced obesity and diabetes. Endocrinology 148 5991-5997.

Arita Y, Kihara S, Ouchi N, Takahashi M, Maeda K, Miyagawa J, Hotta K, Shimomura I, Nakamura T, Miyaoka K et al. 1999 Paradoxical decrease of an adipose-specific protein, adiponectin, in obesity. Biochemical and Biophysical Research Communications 257 79-83.

Berghofer A, Pischon T, Reinhold T, Apovian CM, Sharma AM \& Willich SN 2008 Obesity prevalence from a European perspective: a systematic review. BMC Public Health 8200.

Bhattacharya S, Campbell DM, Liston WA \& Bhattacharya S 2007 Effect of body mass index on pregnancy outcomes in nulliparous women delivering singleton babies. BMC Public Health 7168.

Bodnar LM, Ness RB, Harger GF \& Roberts JM 2005 Inflammation and triglycerides partially mediate the effect of prepregnancy body mass index on the risk of preeclampsia. Americam Journal of Epidemiology 162 1198-1206.

Boney CM, Verma A, Tucker R \& Vohr BR 2005 Metabolic syndrome in childhood: association with birth weight, maternal obesity, and gestational diabetes mellitus. Pediatrics 115 e290-e296.

Boomsma CM, Eijkemans MJ, Hughes EG, Visser GH, Fauser BC \& Macklon NS 2006 A meta-analysis of pregnancy outcomes in women with polycystic ovary syndrome. Human Reproduction Update 12 673-683.

Bowen JM, Chamley L, Keelan JA \& Mitchell MD 2002 Cytokines of the placenta and extra-placental membranes: roles and regulation during human pregnancy and parturition. Placenta 23 257-273.

Bruun JM, Lihn AS, Pedersen SB \& Richelsen B 2005 Monocyte chemoattractant protein-1 release is higher in visceral than subcutaneous human adipose tissue (AT): implication of macrophages resident in the AT. Journal of Clinical Endocrinology and Metabolism 90 2282-2289.

Cartier A, Lemieux I, Almeras N, Tremblay A, Bergeron J \& Despres JP 2008 Visceral obesity and plasma glucose-insulin homeostasis: contributions of interleukin-6 and tumor necrosis factor-alpha in men. Journal of Clinical Endocrinology and Metabolism 93 1931-1938.

Catalano PM, Presley L, Minium J \& Hauguel-de Mouzon S 2009 Fetuses of obese mothers develop insulin resistance in utero. Diabetes Care 32 1076-1080.

Challier JC, Basu S, Bintein T, Minium J, Hotmire K, Catalano PM \& Hauguel-de Mouzon S 2008 Obesity in pregnancy stimulates macrophage accumulation and inflammation in the placenta. Placenta 29 274-281.

Charriere G, Cousin B, Arnaud E, Andre M, Bacou F, Penicaud L \& Casteilla L 2003 Preadipocyte conversion to macrophage. Evidence of plasticity. Journal of Biological Chemistry 278 9850-9855.

Cinti S 2009 Transdifferentiation properties of adipocytes in the adipose organ. American Journal of Physiology. Endocrinology and Metabolism 297 E977-E986.

Colomiere M, Permezel M, Riley C, Desoye G \& Lappas M 2009 Defective insulin signaling in placenta from pregnancies complicated by gestational diabetes mellitus. European Journal of Endocrinology $\mathbf{1 6 0}$ $567-578$.
Demerath EW, Reed D, Rogers N, Sun SS, Lee M, Choh AC, Couch W, Czerwinski SA, Chumlea WC, Siervogel RM et al. 2008 Visceral adiposity and its anatomical distribution as predictors of the metabolic syndrome and cardiometabolic risk factor levels. American Journal of Clinical Nutrition 88 1263-1271.

Denison FC, Price J, Graham C, Wild S \& Liston WA 2008 Maternal obesity, length of gestation, risk of postdates pregnancy and spontaneous onset of labour at term. British Journal of Obstetrics and Gynaecology 115 720-725.

Despres JP \& Lemieux I 2006 Abdominal obesity and metabolic syndrome. Nature $\mathbf{4 4 4} 881-887$.

Dorup I, Skajaa K \& Sorensen KE 1999 Normal pregnancy is associated with enhanced endothelium-dependent flow-mediated vasodilation. American Journal of Physiology 276 H821-H825.

Elchalal U, Schaiff WT, Smith SD, Rimon E, Bildirici I, Nelson DM \& Sadovsky Y 2005 Insulin and fatty acids regulate the expression of the fat droplet-associated protein adipophilin in primary human trophoblasts. American Journal of Obstetrics and Gynecology 193 1716-1723.

Esler M, Rumantir M, Wiesner G, Kaye D, Hastings J \& Lambert G 2001 Sympathetic nervous system and insulin resistance: from obesity to diabetes. American Journal of Hypertension 14 304S-309S.

Esposito K, Pontillo A, Giugliano F, Giugliano G, Marfella R, Nicoletti G \& Giugliano D 2003 Association of low interleukin-10 levels with the metabolic syndrome in obese women. Journal of Clinical Endocrinology and Metabolism 88 1055-1058.

Faber DR, de Groot PG \& Visseren FL 2009 Role of adipose tissue in haemostasis, coagulation and fibrinolysis. Obesity Reviews $\mathbf{1 0}$ 554-563.

Fain JN, Madan AK, Hiler ML, Cheema P \& Bahouth SW 2004 Comparison of the release of adipokines by adipose tissue, adipose tissue matrix, and adipocytes from visceral and subcutaneous abdominal adipose tissues of obese humans. Endocrinology 145 2273-2282.

Farley D, Tejero ME, Comuzzie AG, Higgins PB, Cox L, Werner SL, Jenkins SL, Li C, Choi J, Dick EJ Jr et al. 2009 Feto-placental adaptations to maternal obesity in the baboon. Placenta $30752-760$.

Feuerer M, Herrero L, Cipolletta D, Naaz A, Wong J, Nayer A, Lee J, Goldfine AB, Benoist C, Shoelson S et al. 2009 Lean, but not obese, fat is enriched for a unique population of regulatory $\mathrm{T}$ cells that affect metabolic parameters. Nature Medicine 15 930-939.

Fietta P 2005 Focus on leptin, a pleiotropic hormone. Minerva Medica 96 65-75.

Frisbee JC 2005 Hypertension-independent microvascular rarefaction in the obese Zucker rat model of the metabolic syndrome. Microcirculation 12 383-392.

Frisbee JC 2006 Vascular adrenergic tone and structural narrowing constrain reactive hyperemia in skeletal muscle of obese Zucker rats. American Journal of Physiology. Heart and Circulatory Physiology 290 H2066-H2074.

Di Gregorio GB, Yao-Borengasser A, Rasouli N, Varma V, Lu T, Miles LM, Ranganathan G, Peterson CA, McGehee RE \& Kern PA 2005 Expression of CD68 and macrophage chemoattractant protein-1 genes in human adipose and muscle tissues: association with cytokine expression, insulin resistance, and reduction by pioglitazone. Diabetes $\mathbf{5 4} 2305-2313$.

Gunderson EP, Abrams B \& Selvin S 2001 Does the pattern of postpartum weight change differ according to pregravid body size? International Journal of Obesity and Related Metabolic Disorders 25 853-862.

Guzeloglu-Kayisli O, Kayisli UA \& Taylor HS 2009 The role of growth factors and cytokines during implantation: endocrine and paracrine interactions. Seminars in Reproductive Medicine 27 62-79.

Harman-Boehm I, Bluher M, Redel H, Sion-Vardy N, Ovadia S, Avinoach E, Shai I, Kloting N, Stumvoll M, Bashan N et al. 2007 Macrophage infiltration into omental versus subcutaneous fat across different populations: effect of regional adiposity and the comorbidities of obesity. Journal of Clinical Endocrinology and Metabolism 92 2240-2247.

Hauguel-de Mouzon S \& Guerre-Millo M 2006 The placenta cytokine network and inflammatory signals. Placenta 27 794-798.

Heinonen MV, Purhonen AK, Miettinen P, Paakkonen M, Pirinen E, Alhava E, Akerman K \& Herzig KH 2005 Apelin, orexin-A and leptin plasma levels in morbid obesity and effect of gastric banding. Regulatory Peptides 130 7-13. 
Hellgren M 2003 Hemostasis during normal pregnancy and puerperium. Seminars in Thrombosis and Hemostasis 29 125-130.

Heslehurst N, Ells LJ, Simpson H, Batterham A, Wilkinson J \& Summerbell CD 2007 Trends in maternal obesity incidence rates, demographic predictors, and health inequalities in 36,821 women over a 15-year period. British Journal of Obstetrics and Gynaecology 114 187-194.

Heslehurst N, Rankin J, Wilkinson JR \& Summerbell CD 2009 A nationally representative study of maternal obesity in England, UK: trends in incidence and demographic inequalities in 619323 births, 1989-2007. International Journal of Obesity 34 420-428.

Hétu PO \& Riendeau D 2007 Down-regulation of microsomal prostaglandin $E_{2}$ synthase-1 in adipose tissue by high-fat feeding. Obesity 15 60-68.

Hotamisligil GS 2006 Inflammation and metabolic disorders. Nature $\mathbf{4 4 4}$ 860-867.

Hotamisligil GS, Shargill NS \& Spiegelman BM 1993 Adipose expression of tumor necrosis factor-alpha: direct role in obesity-linked insulin resistance. Science 259 87-91.

Huber J, Kiefer FW, Zeyda M, Ludvik B, Silberhumer GR, Prager G, Zlabinger GJ \& Stulnig TM 2008 CC chemokine and CC chemokine receptor profiles in visceral and subcutaneous adipose tissue are altered in human obesity. Journal of Clinical Endocrinology and Metabolism 93 3215-3221.

Islami D, Bischof P \& Chardonnens D 2003 Modulation of placental vascular endothelial growth factor by leptin and hCG. Molecular Human Reproduction 9 395-398.

Janke J, Engeli S, Gorzelniak K, Luft FC \& Sharma AM 2002 Resistin gene expression in human adipocytes is not related to insulin resistance. Obesity Research $101-5$.

Jones HN, Jansson T \& Powell TL 2009 IL-6 stimulates system A amino acid transporter activity in trophoblast cells through STAT3 and increased expression of SNAT2. American Journal of Physiology. Cell Physiology 297 C1228-C1235.

Juge-Aubry CE, Somm E, Giusti V, Pernin A, Chicheportiche R, Verdumo C, Rohner-Jeanrenaud F, Burger D, Dayer JM \& Meier CA 2003 Adipose tissue is a major source of interleukin-1 receptor antagonist: upregulation in obesity and inflammation. Diabetes 52 1104-1110.

Juge-Aubry CE, Somm E, Pernin A, Alizadeh N, Giusti V, Dayer JM \& Meier CA 2005 Adipose tissue is a regulated source of interleukin-10. Cytokine 29 270-274.

Kern PA, Ranganathan S, Li C, Wood L \& Ranganathan G 2001 Adipose tissue tumor necrosis factor and interleukin-6 expression in human obesity and insulin resistance. American Journal of Physiology. Endocrinology and Metabolism 280 E745-E751.

Kintscher U, Hartge M, Hess K, Foryst-Ludwig A, Clemenz M, Wabitsch M, Fischer-Posovszky P, Barth TF, Dragun D, Skurk T et al. 2008 T-lymphocyte infiltration in visceral adipose tissue: a primary event in adipose tissue inflammation and the development of obesity-mediated insulin resistance. Arteriosclerosis, Thrombosis, and Vascular Biology 28 1304-1310.

Kirwan JP, Hauguel-De Mouzon S, Lepercq J, Challier JC, Huston-Presley L, Friedman JE, Kalhan SC \& Catalano PM 2002 TNF-alpha is a predictor of insulin resistance in human pregnancy. Diabetes $\mathbf{5 1}$ 2207-2213.

Kleiblova P, Dostalova I, Bartlova M, Lacinova Z, Ticha I, Krejci V, Springer D, Kleibl Z \& Haluzik M 2010 Expression of adipokines and estrogen receptors in adipose tissue and placenta of patients with gestational diabetes mellitus. Molecular and Cellular Endocrinology 314 150-156.

Knittle JL, Timmers K, Ginsberg-Fellner F, Brown RE \& Katz DP 1979 The growth of adipose tissue in children and adolescents. Cross-sectional and longitudinal studies of adipose cell number and size. Journal of Clinical Investigation 63 239-246.

de Laat MW, Franx A, van Alderen ED, Nikkels PG \& Visser GH 2005 The umbilical coiling index, a review of the literature. Journal of Maternal Fetal and Neonatal Medicine 17 93-100.

Lago F, Dieguez C, Gomez-Reino J \& Gualillo O 2007 The emerging role of adipokines as mediators of inflammation and immune responses. Cytokine and Growth Factor Reviews 18 313-325.

Lappas M, Permezel M \& Rice GE 2005 Leptin and adiponectin stimulate the release of proinflammatory cytokines and prostaglandins from human placenta and maternal adipose tissue via nuclear factor-kappaB, peroxisomal proliferator-activated receptor-gamma and extracellularly regulated kinase 1/2. Endocrinology 146 3334-3342.

Lappas M, Mittion A \& Permezel M 2010 In response to oxidative stress, the expression of inflammatory cytokines and antioxidant enzymes are impaired in placenta, but not adipose tissue, of women with gestational diabetes. Journal of Endocrinology 204 75-84.

Lepercq J, Cauzac M, Lahlou N, Timsit J, Girard J, Auwerx J \& Haugel-de Mouzon S 1998 Overexpression of placental leptin in diabetic pregnancy: a critical role for insulin. Diabetes 47 847-850.

Liu J, Divoux A, Sun J, Zhang J, Clement K, Glickman JN, Sukhova GK, Wolters PJ, Du J, Gorgun CZ et al. 2009 Genetic deficiency and pharmacological stabilization of mast cells reduce diet-induced obesity and diabetes in mice. Nature Medicine 15 940-945.

Lumeng CN, Bodzin JL \& Saltiel AR 2007 Obesity induces a phenotypic switch in adipose tissue macrophage polarization. Journal of Clinical Investigation 117 175-184.

Lumeng CN, Maillard I \& Saltiel AR 2009 T-ing up inflammation in fat. Nature Medicine 15 846-847.

Macia L, Delacre M, Abboud G, Ouk TS, Delanoye A, Verwaerde C, Saule P \& Wolowczuk I 2006 Impairment of dendritic cell functionality and steady-state number in obese mice. Journal of Immunology 177 5997-6006.

Madazli R, Tuten A, Calay Z, Uzun H, Uludag S \& Ocak V 2008 The incidence of placental abnormalities, maternal and cord plasma malondialdehyde and vascular endothelial growth factor levels in women with gestational diabetes mellitus and nondiabetic controls. Gynecologic and Obstetric Investigation 65 227-232.

Makkonen J, Westerbacka J, Kolak M, Sutinen J, Corner A, Hamsten A, Fisher RM \& Yki-Jarvinen H 2007 Increased expression of the macrophage markers and of $11 \beta-H S D-1$ in subcutaneous adipose tissue, but not in cultured monocyte-derived macrophages, is associated with liver fat in human obesity. International Journal of Obesity 31 1617-1625.

Maroof A, English NR, Bedford PA, Gabrilovich DI \& Knight SC 2005 Developing dendritic cells become 'lacy' cells packed with fat and glycogen. Immunology 115 473-483.

Martin AM, Berger H, Nisenbaum R, Lausman AY, MacGarvie S, Crerar C \& Ray JG 2009 Abdominal visceral adiposity in the first trimester predicts glucose intolerance in later pregnancy. Diabetes Care 32 1308-1310.

Maury E \& Brichard SM 2010 Adipokine dysregulation, adipose tissue inflammation and metabolic syndrome. Molecular and Cellular Endocrinology 314 1-16.

Meier CA, Bobbioni E, Gabay C, Assimacopoulos-Jeannet F, Golay A \& Dayer JM 2002 IL-1 receptor antagonist serum levels are increased in human obesity: a possible link to the resistance to leptin? Journal of Clinical Endocrinology and Metabolism 87 1184-1188.

Metzger BE, Lowe LP, Dyer AR, Trimble ER, Chaovarindr U, Coustan DR, Hadden DR, McCance DR, Hod M, Mclntyre HD et al. 2008 Hyperglycemia and adverse pregnancy outcomes. New England Journal of Medicine 358 1991-2002.

Morton NM \& SeckI JR 2008 11ß-Hydroxysteroid dehydrogenase type 1 and obesity. Frontiers of Hormone Research 36 146-164.

Myers J, Hall C, Wareing M, Gillham J \& Baker P 2006 The effect of maternal characteristics on endothelial-dependent relaxation of myometrial arteries. European Journal of Obstetrics, Gynecology, and Reproductive Biology 124 158-163.

Nelson SM, Coan PM, Burton GJ \& Lindsay RS 2009 Placental structure in type 1 diabetes: relation to fetal insulin, leptin, and IGF-I. Diabetes $\mathbf{5 8}$ 2634-2641.

Nishimura S, Manabe I, Nagasaki M, Eto K, Yamashita H, Ohsugi M, Otsu M, Hara K, Ueki K, Sugiura S et al. 2009 CD8+ effector T cells contribute to macrophage recruitment and adipose tissue inflammation in obesity. Nature Medicine 15 914-920.

Oken E, Rifas-Shiman SL, Field AE, Frazier AL \& Gillman MW 2008 Maternal gestational weight gain and offspring weight in adolescence. Obstetrics and Gynecology 112 999-1006.

Paiva P, Salamonsen LA, Manuelpillai U, Walker C, Tapia A, Wallace EM \& Dimitriadis E 2007 Interleukin-11 promotes migration, but not proliferation, of human trophoblast cells, implying a role in placentation. Endocrinology 148 5566-5572. 
Pang ZJ, Zhou JG \& Huang LP 2008 Interleukin-10 may participate in regulating trophoblast invasion in human placentae throughout gestation. American Journal of Reproductive Immunology 60 19-25.

Paulsen SK, Pedersen SB, Fisker S \& Richelsen B 2007 11 $\beta$-HSD type 1 expression in human adipose tissue: impact of gender, obesity, and fat localization. Obesity 15 1954-1960.

Perez-Perez A, Maymo J, Gambino Y, Duenas JL, Goberna R, Varone C \& Sanchez-Margalet V 2009 Leptin stimulates protein synthesis-activating translation machinery in human trophoblastic cells. Biology of Reproduction 81 826-832.

Poissonnet CM, Burdi AR \& Bookstein FL 1983 Growth and development of human adipose tissue during early gestation. Early Human Development 8 1-11.

Poissonnet CM, Burdi AR \& Garn SM 1984 The chronology of adipose tissue appearance and distribution in the human fetus. Early Human Development 10 1-11.

Poulain-Godefroy O, Lecoeur C, Pattou F, Fruhbeck G \& Froguel P 2008 Inflammation is associated with a decrease of lipogenic factors in omental fat in women. American Journal of Physiology. Regulatory, Integrative and Comparative Physiology 295 R1-R7.

Radaelli T, Varastehpour A, Catalano P \& Hauguel-de Mouzon S 2003 Gestational diabetes induces placental genes for chronic stress and inflammatory pathways. Diabetes 52 2951-2958.

Radaelli T, Lepercq J, Varastehpour A, Basu S, Catalano PM \& Hauguel-De Mouzon S 2009 Differential regulation of genes for fetoplacental lipid pathways in pregnancy with gestational and type 1 diabetes mellitus. American Journal of Obstetrics and Gynecology 201 209.e1-209.e10.

Ramsay JE, Ferrell WR, Crawford L, Wallace AM, Greer IA \& Sattar N 2002 Maternal obesity is associated with dysregulation of metabolic, vascular, and inflammatory pathways. Journal of Clinical Endocrinology and Metabolism 87 4231-4237.

Rasouli N \& Kern PA 2008 Adipocytokines and the metabolic complications of obesity. Journal of Clinical Endocrinology and Metabolism 93 S64-S73.

Robb AO, Mills NL, Din JN, Cameron S, Ludlam CA, Newby DE \& Denison FC 2009a Acute endothelial tissue plasminogen activator release in pregnancy. Journal of Thrombosis and Haemostasis 7 138-142.

Robb AO, Mills NL, Din JN, Smith IB, Paterson F, Newby DE \& Denison FC $2009 \mathrm{~b}$ Influence of the menstrual cycle, pregnancy, and preeclampsia on arterial stiffness. Hypertension 53 952-958.

Roberts VH, Smith J, McLea SA, Heizer AB, Richardson JL \& Myatt L 2009 Effect of increasing maternal body mass index on oxidative and nitrative stress in the human placenta. Placenta 30 169-175.

Rusterholz C, Hahn S \& Holzgreve W 2007 Role of placentally produced inflammatory and regulatory cytokines in pregnancy and the etiology of preeclampsia. Seminars in Immunopathology 29 151-162.

Sabio G, Das M, Mora A, Zhang Z, Jun JY, Ko HJ, Barrett T, Kim JK \& Davis RJ 2008 A stress signaling pathway in adipose tissue regulates hepatic insulin resistance. Science 322 1539-1543.

Sacks GP, Studena K, Sargent K \& Redman CW 1998 Normal pregnancy and preeclampsia both produce inflammatory changes in peripheral blood leukocytes akin to those of sepsis. American Journal of Obstetrics and Gynecology 179 80-86.

Sacks GP, Seyani L, Lavery S \& Trew G 2004 Maternal C-reactive protein levels are raised at 4 weeks gestation. Human Reproduction 19 1025-1030.

Sattar N \& Greer IA 2002 Pregnancy complications and maternal cardiovascular risk: opportunities for intervention and screening? BMJ 325 157-160.

Schaeffler A, Gross P, Buettner R, Bollheimer C, Buechler C, Neumeier M, Kopp A, Schoelmerich J \& Falk W 2009 Fatty acid-induced induction of Toll-like receptor-4/nuclear factor-kappaB pathway in adipocytes links nutritional signalling with innate immunity. Immunology $\mathbf{1 2 6}$ 233-245.

Sebire NJ 2007 Pathophysiological significance of abnormal umbilical cord coiling index. Ultrasound Obstetrics and Gynecology 30 804-806.

Sebire NJ, Jolly M, Harris JP, Wadsworth J, Joffe M, Beard RW, Regan L \& Robinson S 2001 Maternal obesity and pregnancy outcome: a study of 287,213 pregnancies in London. International Journal of Obesity and Related Metabolic Disorders 25 1175-1182.
Singh U, Yu Y, Kalinina E, Konno T, Sun T, Ohta H, Wakayama T, Soares MJ, Hemberger M \& Fundele RH 2006 Carboxypeptidase E in the mouse placenta. Differentiation 74 648-660.

Spalding KL, Arner E, Westermark PO, Bernard S, Buchholz BA, Bergmann O, Blomqvist L, Hoffstedt J, Naslund E, Britton T et al. 2008 Dynamics of fat cell turnover in humans. Nature 453 783-787.

Stapleton PA, James ME, Goodwill AG \& Frisbee JC 2008 Obesity and vascular dysfunction. Pathophysiology 15 79-89.

Steinberg HO, Chaker H, Leaming R, Johnson A, Brechtel G \& Baron AD 1996 Obesity/insulin resistance is associated with endothelial dysfunction. Implications for the syndrome of insulin resistance. Journal of Clinical Investigation 97 2601-2610.

Stepp DW \& Belin De Chantemele EJ 2007 Structural remodeling in the limb circulation: impact of obesity and diabetes. Microcirculation 14 311-316.

Steppan CM \& Lazar MA 2002 Resistin and obesity-associated insulin resistance. Trends in Endocrinology and Metabolism 13 18-23.

Stewart FM, Freeman DJ, Ramsay JE, Greer IA, Caslake M \& Ferrell WR 2007 Longitudinal assessment of maternal endothelial function and markers of inflammation and placental function throughout pregnancy in lean and obese mothers. Journal of Clinical Endocrinology and Metabolism 92 969-975.

Straczkowski M, Dzienis-Straczkowska S, Stêpieñ A, Kowalska I, Szelachowska M \& Kinalska I 2002 Plasma interleukin-8 concentrations are increased in obese subjects and related to fat mass and tumor necrosis factor-alpha system. Journal of Clinical Endocrinology and Metabolism 87 4602-4606.

Sturm W, Sandhofer A, Engl J, Laimer M, Molnar C, Kaser S, Weiss H, Tilg H, Ebenbichler CF \& Patsch JR 2009 Influence of visceral obesity and liver fat on vascular structure and function in obese subjects. Obesity $\mathbf{1 7}$ 1783-1788.

Swanson LD \& Bewtra C 2008 Increase in normal placental weights related to increase in maternal body mass index. Journal of Maternal Fetal and Neonatal Medicine 21 111-113.

Tateya S, Tamori Y, Kawaguchi T, Kanda H \& Kasuga M 2010 An increase in the circulating concentration of monocyte chemoattractant protein-1 elicits systemic insulin resistance irrespective of adipose tissue inflammation in mice. Endocrinology 151 971-979.

Telejko B, Kuzmicki M, Zonenberg A, Szamatowicz J, WawrusiewiczKurylonek N, Nikolajuk A, Kretowski A \& Gorska M 2009 Visfatin in gestational diabetes: serum level and mRNA expression in fat and placental tissue. Diabetes Research and Clinical Practice 84 68-75.

Tordjman J, Poitou C, Hugol D, Bouillot JL, Basdevant A, Bedossa P, Guerre-Millo M \& Clement K 2009 Association between omental adipose tissue macrophages and liver histopathology in morbid obesity: influence of glycemic status. Journal of Hepatology $\mathbf{5 1}$ 354-362.

Traupe T, Lang M, Goettsch W, Munter K, Morawietz H, Vetter W \& Barton M 2002 Obesity increases prostanoid-mediated vasoconstriction and vascular thromboxane receptor gene expression. Journal of Hypertension 20 2239-2245.

Van Guilder GP, Hoetzer GL, Dengel DR, Stauffer BL \& DeSouza CA 2006 Impaired endothelium-dependent vasodilation in normotensive and normoglycemic obese adult humans. Journal of Cardiovascular Pharmacology 47 310-313.

Varastehpour A, Radaelli T, Minium J, Ortega H, Herrera E, Catalano P \& Hauguel-de Mouzon S 2006 Activation of phospholipase A2 is associated with generation of placental lipid signals and fetal obesity. Journal of Clinical Endocrinology and Metabolism 91 248-255.

Wake DJ, Strand M, Rask E, Westerbacka J, Livingstone DE, Soderberg S, Andrew R, Yki-Jarvinen H, Olsson T \& Walker BR 2007 Intra-adipose sex steroid metabolism and body fat distribution in idiopathic human obesity. Clinical Endocrinology 66 440-446.

Walsh SW 2007 Obesity: a risk factor for preeclampsia. Trends in Endocrinology and Metabolism 18 365-370.

Weisberg SP, McCann D, Desai M, Rosenbaum M, Leibel RL \& Ferrante AW Jr 2003 Obesity is associated with macrophage accumulation in adipose tissue. Journal of Clinical Investigation 112 1796-1808.

Wellen KE \& Hotamisligil GS 2003 Obesity-induced inflammatory changes in adipose tissue. Journal of Clinical Investigation 112 1785-1788. 
Winer S, Chan Y, Paltser G, Truong D, Tsui H, Bahrami J, Dorfman R, Wang Y, Zielenski J, Mastronardi F et al. 2009 Normalization of obesityassociated insulin resistance through immunotherapy. Nature Medicine 15 921-929.

Xu H, Barnes GT, Yang Q, Tan G, Yang D, Chou CJ, Sole J, Nichols A, Ross JS, Tartaglia LA et al. 2003 Chronic inflammation in fat plays a crucial role in the development of obesity-related insulin resistance. Journal of Clinical Investigation 112 1821-1830.

Yang Q, Graham TE, Mody N, Preitner F, Peroni OD, Zabolotny JM, Kotani K, Quadro L \& Kahn BB 2005 Serum retinol binding protein 4 contributes to insulin resistance in obesity and type 2 diabetes. Nature 436 356-362.

Zebekakis PE, Nawrot T, Thijs L, Balkestein EJ, van der Heijden-Spek J, Van Bortel LM, Struijker-Boudier HA, Safar ME \& Staessen JA 2005 Obesity is associated with increased arterial stiffness from adolescence until old age. Journal of Hypertension 23 1839-1846.

Zeyda M \& Stulnig TM 2007 Adipose tissue macrophages. Immunology Letters 112 61-67.

Zeyda M, Farmer D, Todoric J, Aszmann O, Speiser M, Gyori G, Zlabinger GJ \& Stulnig TM 2007 Human adipose tissue macrophages are of an anti-inflammatory phenotype but capable of excessive pro-inflammatory mediator production. International Journal of Obesity 31 1420-1428.

Zhang H \& Zhang C 2009 Regulation of microvascular function by adipose tissue in obesity and type 2 diabetes: evidence of an adipose-vascular loop. American Journal of Biomedical Sciences 1 133-142.

Zhang Y, Proenca R, Maffei M, Barone M, Leopold L \& Friedman JM 1994 Positional cloning of the mouse obese gene and its human homologue. Nature 372 425-432.

Zhou Y, Zhang M, Guo W, Yu M, Xue K, Huang S, Chen Y, Zhu H, Xu L \& Guo T 2006 Expression of resistin protein in normal human subcutaneous adipose tissue and pregnant women subcutaneous adipose tissue and placenta. Journal of Huazhong University of Science and Technology. Medical Sciences 26 288-291.

Received 4 February 2010

First decision 9 March 2010

Accepted 9 March 2010 